\section{MACRO IMPLICATIONS OF HOUSEHOLDS' REINVESTMENT BEHAVIOUR IN EXISTING HOUSING STOCK}

\author{
Ö. Burcu ÖZDEMIR SARI
}

Received: 05.04.2011, Final Text: 06.10.2011

Keywords: residential reinvestment; rehabilitation; household behaviour; housing policy; housing sector in Turkey.

1. Repairs and maintenance activities could cover minor repairs (e.g., regular maintenance and repairs, painting, replacement of door-window frames), major repairs (e.g., replacement of kitchen-bath systems, installations like plumbing or electrical systems), and / or structural repairs (e.g., covering external surfaces and roof, foundation consolidation or retrofitting against seismic and other hazards). Whereas, rehabilitation investments comprise conversions, extensions, upgrading, joining and subdividing operations in buildings.
Reinvestments refer to repairs and maintenance activities, as well as rehabilitation investments undertaken with the purposes of improving existing housing assets and standard of life (1). Reinvestment behaviour of household $(\mathrm{Hh})$ in housing has been investigated for more than four decades in the literature. Macro implications of individual behaviour however, remain largely neglected. Hhs' reinvestment behaviour and expenditures could have impacts in the depreciation of the housing stock, quality of housing and neighbourhood services, residential adjustment options, housing supply, etc. In Turkey, although substantial capital is engaged in reinvestments in the existing housing stock, no tool or mechanism exists associated with the monitoring of reinvestments. Yet, Hhs' reinvestment decisions and expenditures are likely to play a crucial role in trajectory of Turkish housing stock, neighbourhoods, and in overall economy. Furthermore, in the current phase of urbanization in Turkey there are numerous reasons that necessitate purposeful design and implementation of reinvestment policies. Understanding Hh reinvestment behaviour and identifying its macro implications would contribute to the monitoring of the economic system, as well as to urban decision-makers and planners in designing finer policies and tools of intervention to tackle problems of the existing housing stock and neighbourhood environments.

\section{INTRODUCTION: REINVESTMENT PROCESSES AND POLICIES IN HOUSING}

Reinvestments and Hhs' reinvestment behaviour in existing housing stock have captured attention of researchers in Europe and in the US since the late 1960s due to changing housing policies by the end of that decade. Housing shortages have been the major problem in many European countries after the Second World War, and quantity of housing remained as a problem until the end of 1960s. Public policy and allocation of resources aimed at new construction with the purposes of increasing housing supply, 
and minor attention was paid to improvements in the existing housing stock (Skifter Andersen, 1999). In the late 1960s, elimination of housing shortage to some extent, and intolerable living conditions faced in aged housing stock resulted in a policy shift highlighting qualitative aspects of housing. It was not only the economic burden of redevelopment but also social objections stemming from the earlier massive clearance experiences that compelled administrations to search for alternative methods of improving poor housing conditions. On the other hand, in the US, largescale redevelopment projects operated in the deprived and declining urban areas resulted in the displacement of many poor urban Hhs, worsening their housing conditions rather than improving it. As a result, both in European countries and in the US, interest in the means of improvement and rehabilitation in existing housing stock increased, and brought Hhs to the centre of policy-making as the main actors of reinvestment decisions.

Although reinvestment decision is a micro level activity, Hhs' decisions often have broader implications at the macro level beyond improvements in Hhs' individual well-being. Some of these implications can be observed directly in the built environment, for instance, in the depreciation of the housing stock, and quality of housing and neighbourhood services. Further implications can be traced in the overall economy, in terms of total volume of capital engaged in reinvestments in comparison to new construction, volume of production activity for materials employed in reinvestment operations, etc. Owing to the Hhs' central position in reinvestment decisions, Hh reinvestment behaviour has extensively been investigated by numerous research efforts in the world scientific literature. Macro implications of individual reinvestment behaviour however, remain largely neglected.

Contrary to many European countries and the US, the problem of housing has been largely considered as a quantitative deficiency problem for many decades in Turkey. Therefore, the focus of housing policies and urban planning has been confined to 'urban growth' and 'new stock production', and reinvestments in existing housing stock have attracted almost no attention. Turkish Hhs, dominantly owner-occupiers as in most countries, are the main decision-makers of reinvestments in housing. Annual reinvestment expenditures of urban Hhs in housing were nearly 1.42 billion Euros in 2008 (TURKSTAT, 2002-08) (2). This corresponds roughly to 10 per cent of the value of private residential investments for new construction in the same year. Although reinvestment in the existing housing stock is a current urban economic trend in Turkey, it still remains almost unnoticed by researchers and policy makers. Macro level outcomes and social implications of $\mathrm{Hhs}^{\prime}$ reinvestment behaviour need to be traced for the development of specific response and guidance policies. Therefore, in this article first macro implications of Hhs' reinvestment behaviour are reviewed based on the previous research in the field, and existing

2. This figure is actually an underestimation since related data in Household Budget Survey (HBS) is based on monthly data which ignore seasonal differences in reinvestments and payments done in installments. policy approaches to reinvestment processes in some European countries are surveyed. Then, aggregate outcomes of Turkish Hhs' reinvestments in the existing housing stock are explored, and the reasons to consider reinvestment policies as a requirement for monitoring the existing housing stock in Turkey are discussed. 
3. This part of the article is partly derived from Özdemir Sarı (2007).

\section{MACRO IMPLICATIONS OF HOUSEHOLDS' REINVESTMENT BEHAVIOUR (3)}

\section{Reinvestment Behaviour and Depreciation of Housing}

In the housing literature, depreciation is broadly defined as the decline in house values due to aging. This definition is broad enough to cover both physical deterioration and other processes of obsolescence (Lichfield, 1956). Central in the field of maintenance theory is the relationship between Hhs' maintenance expenditures and depreciation rates of housing (Sweeney, 1974; Chinloy, 1980; Arnott et al., 1983; Shilling et al., 1991; Knight and Sirmans, 1996; Harding et al., 2007; Wilhelmsson, 2008). Hhs' reinvestments for maintenance are argued to slow or even reverse the effects of depreciation on the value of housing services. Findings of a recent empirical study indicate that in the absence of maintenance, housing depreciates at approximately 2.5 per cent per year of its value, while maintenance lowers the depreciation rate to roughly 2 per cent per year (Harding et al., 2007). Moreover, poorly maintained houses are displayed to depreciate at a much faster rate, by almost 1 per cent per year, than do houses with average maintenance, and that well-maintained houses has had the effects of age retarded by 0.17 per cent per year (Knight and Sirmans, 1996).

In this context, the relationship between 'mode of tenure' and 'tendency to maintain' has also been attended. It is argued that owner-occupied housing units tend to be better maintained than rental units (Grigsby, 1963; Sweeney, 1974; Shilling et al., 1991). Empirical evidence supports this argument displaying that tenant-occupied dwellings depreciate faster than owner-occupied ones approximately 0.5 per cent per year of their values (Shilling et al., 1991). Moreover, owner-occupant landlords in proximity to their rented property are displayed to have higher likelihood of rehabilitation investment tendencies than landlords residing elsewhere (Mayer, 1981). Consequently, Hhs' reinvestments help effective use of housing by preserving or even improving the standards of both physical structure of the housing unit and the services provided by it. In the absence of Hhs' reinvestments, accelerated asset value decline, and losses from the existing housing inventory is unavoidable.

\section{Reinvestment Behaviour and Neighbourhood Quality}

Hhs' reinvestment behaviour is not only seen as a determinant of housing quality but also of the asset value of nations' housing stock and, quality of neighbourhoods (Winger, 1973; Dildine and Massey, 1974; Galster, 1987; Littlewood and Munro, 1996). Accordingly, understanding the behaviour of individual agents, contributing to the aggregate dynamics, is considered a precondition to understand neighbourhood dynamics (Galster, 1987). Studies in this context analyse Hhs' reinvestment behaviour in order to elaborate an understanding of neighbourhood change. Depending on the high share of privately-owned dwellings in US cities, it is argued that basically the current reinvestment decisions of private owners (decisions to repair, modernize, or expand existing houses) determine the changes in housing quality in many neighbourhoods, rather than new construction or direct governmental action (Dildine and Massey, 1974). A similar argument is maintained also for the UK where owner-occupation has been the dominant tenure since the 1970s. Accordingly, the majority of British Hhs have a role both in the production, and in the consumption of housing services, being responsible for the maintenance of the greater 
part of the housing stock; therefore, the problem of disrepair in housing can be explained by examining why owner-occupier Hhs refrain from reinvestments (Littlewood and Munro, 1996). These imply that Hhs' reinvestment behaviour is a key for maintaining and improving the quality and the standards of housing services and living environments in cities.

\section{Reinvestment Behaviour and Housing Adjustment Options}

In the context of housing consumption adjustments, Hhs' reinvestment and mobility decisions are believed to be correlated (Seek, 1983; Shear, 1983; Boehm and Ihlanfeldt, 1986; Potepan, 1989; Montgomery, 1992; Littlewood and Munro, 1997; Baum and Hassan, 1999; Mandič, 2001; Sinai, 2001). The need for adjustments arises when Hhs are faced with a discrepancy between the desired or optimal level of housing consumption and the actual one. For some researchers, Hhs' adjustment options are limited to a simultaneous decision between the discrete alternatives of moving or improving (Shear, 1983; Boehm and Ihlanfeldt, 1986; Potepan, 1989; Montgomery, 1992; Sinai, 2001). For others, moving and improving decisions can be integrated, providing a viable alternative adjustment option to Hhs (Seek, 1983; Littlewood and Munro, 1997; Baum and Hassan, 1999; Mandič, 2001). This implies that Hhs may not intend to reach desired level of housing at the time of moving, rather they can deliberately choose a relatively lower amount of housing services with the intention of improving it through time (Littlewood and Munro, 1997). Then, it is possible to observe the move and improve strategy through reinvestment behaviour and expenditures of recent mover Hhs. Moreover, recent movers are displayed to undertake more consumption oriented investments, whereas Hhs with mobility plans in the near future are often engaged in investments aimed towards selling, if at all (Littlewood and Munro, 1997). These two different motives have differing implications on the quality and on the value of the existing housing stock. Consequently, Hhs' reinvestment decisions must be considered as an integral part of mobility decisions in order to develop a better understanding of housing adjustments.

\section{Reinvestment Behaviour and Residential Investments}

In many countries, means of monitoring reinvestment processes have become a focal tool of housing policies, and measures have been developed to encourage Hhs' reinvestments. These are usually partial financial supports to reinvestment expenditure, and they are conditional upon $\mathrm{Hh}$ and dwelling attributes. With these supports, volumes of reinvestment expenditures realized by Hhs have grown in time, and have become almost as significant as investments in new construction. Consequently, the attention given in the residential investment debates has intensified, and exploration of the nature of reinvestments (determinants, incidence, timing, etc.) is claimed to be a precondition for a thorough understanding of residential investments (Mendelsohn, 1977; Boehm and Ihlanfeldt, 1986; Galster, 1987; Potepan, 1989; Montgomery, 1992; Bogdon, 1992; Reschovsky, 1992; Holmans, 2004).

It was estimated for US cities that, volume of reinvestment expenditures in housing was approximately 59 per cent of the value of new housing construction in year 2000, and 68 per cent of the reinvestment expenditures were realized by homeowners (4). Also in France, where some subsidies are available both for new construction and for reinvestment works, the share of reinvestments in total residential investments was around 60 per

4. Data related to 'expenditures for residential improvements and repairs', and 'value of new construction put in place' are obtained from U.S. Census Bureau, Current Construction Reports, C50/01-Q1 and C30/01-1, www.census.gov. 
cent in 1993 (Donner, 2000). This ratio remained approximately 50 per cent during 2000-2002, despite declining state aid to reinvestments (Ball, 2005). It is usually assumed that demand for investment in housing is dominantly for new construction. Yet, there is the possibility of investing for rehabilitation by improving the existing housing stock (reinvestments), and without an understanding of the nature and volume of reinvestments; an understanding of housing investments remains incomplete (Montgomery, 1992).

\section{Reinvestment Behaviour and Housing Supply}

Improvement of the existing housing stock and Hhs' reinvestment decisions are also relevant in the context of housing supply. Several studies indicate that in forecasting future housing supply, adjustments to the existing housing inventory must be taken into account as an alternative mechanism to the production of new housing (Merrett, 1982; Boehm and Ihlanfeldt, 1986; Potepan, 1989; Dipasquale, 1999). Since housing is a durable good, not only new housing production decisions, but also reinvestment decisions in existing housing stock are the determiners of housing supply. Conversions of uses, extensions, upgrading, joining and subdividing decisions in existing housing stock are among reinvestments that can affect supply of housing. However, very little is known about the scale of these investment initiatives and about their contribution to the housing inventory. A better understanding of home improvement decisions could lead to more effective housing policies, since these improvements are primary supply adjustment mechanisms in existing neighbourhoods (Mendelsohn, 1977).

It is possible to extend the list of macro implications of Hhs' reinvestment behaviour. A number of conclusions can be derived from the literature reviewed above. Accordingly Hhs' reinvestments for repairs maintenance, and rehabilitation:

- prevent losses from existing inventory,

- extend economic life of the housing stock,

- preserve asset values and ensure value increases,

- improve the standards of housing services and living environments,

- help to adjust housing consumption with regard to the current needs and trends,

- act as a supply adjustment mechanism and reduce number of moves.

Thus, it is not only individual Hhs but also overall economy that is affected by reinvestment decisions. In this respect, reinvestment decisions comprise both a major social policy area and a significant topic of research and implementations in urban studies and planning. Therefore, developing an understanding of Hhs' reinvestment behaviour is a contribution to urban decision-makers and planners in designing finer policies and interventions for existing housing stock and neighbourhoods.

\section{EXISTING POLICY APPROACHES TO REINVESTMENT PROCESSES}

In countries, where the role of Hhs in reinvestment processes is well understood, policies and programmes have been developed to trigger and channel Hhs' reinvestment tendencies. Measures and instruments for this purpose are basically provided as part of the planning legislation, building 
codes, tax legislation, and rent acts. In some cases special legislation for reinvestment works are prepared. Policies target especially Hhs who are unable or unwilling to reinvest to their dwellings or dwelling units which are in urgent need of reinvestments.

In the UK and Sweden for instance, planning legislation provides local authorities with powers to compel owners to renovate or sell their properties. Yet, these types of direct measures are seldom used (Skifter Andersen, 1999). In some cases, regulation of tenure provides a number of useful instruments for housing rehabilitation. For example, in regulated buildings of Danish private rented housing, rents are determined with respect to expenditures which cover running costs (cleaning, taxes, insurances etc.), a fixed capital yield to the landlord, a certain amount per dwelling for administration as well as fixed transferences for maintenance (Skifter Andersen, 2008). Money collected for maintenance is allocated between a maintenance account for the property and a central fund which is employed for housing rehabilitation in private rented sector (Hansen and Skifter Andersen 1999). Regulation through the taxation of property is another instrument for building a capacity and triggering Hhs' reinvestment decisions. For instance in France, tax relief provides a significant incentive for improvements and repairs in owner-occupied housing of specified age. The tax reduction is basically 20 per cent of the total improvement costs with a certain ceiling, which increases with the number of children in the family (Oxley et.al, 1999).

In addition to these, provision of grants -usually from the general housing finance system through special schemes- is among the most frequently employed instruments. This is an indirect regulation to make reinvestments attractive. For instance, in the UK, grants for different tenure types are provided (subject to means-test) to improve the standards of housing services and living environments both at single property level upon individual application, and at renewal areas as declared by local authorities. Designation of renewal areas is another instrument for intervening in the existing housing stock and environments experiencing many problems. This instrument is usually provided by special programmes. It makes possible for local authorities to cope with the problems simultaneously by the concentration of public investment in the defined area, generating economies of scale, and greater degree of control over materials used and higher level of expertise which secure higher standards (Leather, 1999, 2000).

Due to above mentioned measures and instruments to encourage and channel Hhs' reinvestment tendencies, reinvestments in existing housing stock have become a significant urban economic activity in many countries. In the Turkish case, unlike other countries, there are no specified policies to consider reinvestment process in the existing housing stock, and no tool or mechanism exits to encourage or supervise Hhs' reinvestment. Yet, current levels of reinvestments in urban areas have increased to such significant magnitudes that its implications for the overall economy, built environment, and society have to be taken into account.

\section{HOUSEHOLDS AS ACTORS OF REINVESTMENTS IN TURKEY}

Nearly 98.5 per cent of the housing stock in Turkey, both owner-occupied and rented, is privately owned. In urban areas, 60 per cent of Hhs are owner-occupiers and 28 per cent of Hhs are tenants in the privately owned 
5. Almost 1.5 per cent of the stock is public housing in Turkey, and allocated to public officers only. The remaining 10.5 per cent are Hhs living with parents or in relatives' dwellings.

6. Calculation of Hhs' annual reinvestment expenditures are based on the average monthly estimates provided by HBSs of TURKSTAT (2002-2008).

7. Annual value of private residential investments for new construction was approximately 14.3 billion Euros in urban areas in 2008. Data employed in this calculation is construction permit statistics provided by TURKSTAT, www.tuik.gov. tr. Value of private residential investments in new construction is calculated for settlements with 20,001 and more inhabitants in order to obtain comparable results with HBS data. stock by 2008 (TURKSTAT, 2002-08) (5). Existing urban housing stock is dominated by apartment blocks produced under 'Flat Ownership' relations (Balamir, 1975, 1992). Almost 75.5 per cent of the urban Hhs were estimated to live in flats by year 2008 (TURKSTAT, 2002-08). According to the article 19 of the Flat Ownership Law (1965), flat owners are obliged to maintain and preserve the architectural properties as well as structural qualities of the property. Therefore, Hhs are the main decision-makers of reinvestments in housing rather than some external authority.

Reinvestment decisions and expenditures of Turkish Hhs have significant implications for the existing housing stock and neighbourhoods, as well as the overall economy which have to be taken into account. For instance, reinvestments in existing housing stock are significant components of housing investments in urban Turkey. Figure $\mathbf{1}$ displays the annual reinvestment expenditures of Hhs in urban Turkey. Accordingly, annual value of urban Hhs' reinvestment expenditures in housing were nearly 1.42 billion Euros in 2008 despite the recessive effects of global economic crises (TURKSTAT, 2002-08) (6). This volume is actually an underestimate since it is based on monthly data where seasonal differences in reinvestments and payments done in instalments are disregarded. It must also be underlined that these expenditures are realized in such an environment that no policy measure or instrument exists to encourage Hhs' reinvestments. Nevertheless, total volume of Hhs' reinvestment expenditures is significant in magnitude given that it corresponds roughly to 10 per cent of the value of private residential investments for new construction in 2008 (7). Nearly 32 thousand new dwelling units could have been produced with that amount of investment in the same year. Total volume of Hhs' reinvestment expenditures is likely to increase relatively as the existing stock ages and new buildings are added to the inventory. Reinvestments in the existing housing stock and new residential investments could be considered as complementary mechanisms of housing investment processes and policies.

Moreover, Turkish Hhs' reinvestment decisions have implications in the depreciation of the housing stock and thereby for neighbourhood quality. As mentioned above, almost all of the housing stock in Turkey is privately owned, and all types of reinvestments are totally dependent on Hhs'

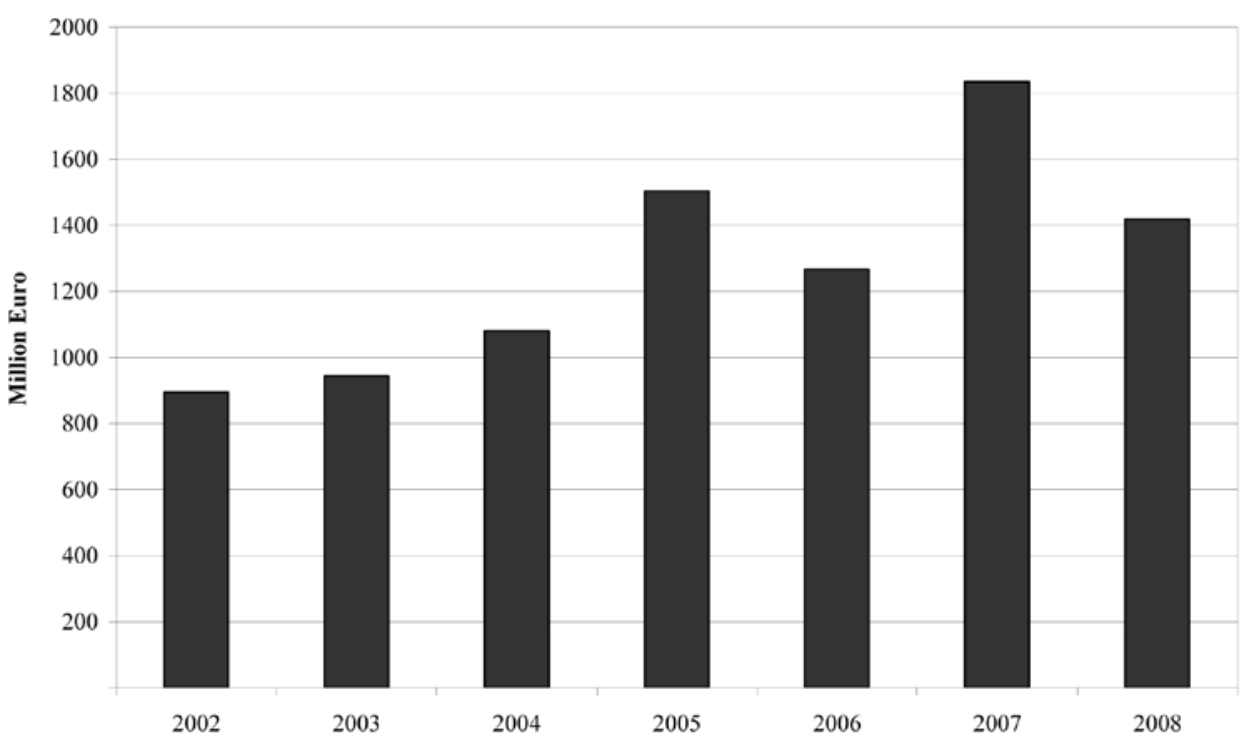

Figure 1. Annual Reinvestment Expenditures in Urban Turkey by Households: 2002-2008 (2008 constant prices). TURKSTAT, Household Consumption Expenditure Database (2002-08). 
decisions in the free market. Therefore, Hhs' reinvestment decisions have a crucial role in the future of nation's housing stock and neighbourhoods. Three types of Hhs can be identified in the Turkish system with respect to 'mode of tenure': owner-occupants, tenants, and owners of the rental stock. Each Hh type has different motives and incentives in undertaking reinvestment work. It is the Hhs' consumption or investment motives, at any point in time, which determine their decisions related to their dwellings. Thus, reinvestment behaviour of owner-occupiers and Hhs capable of renting their housing property are different in nature. For owner-occupiers, reinvestments provide both consumption and investment benefits; however, rental stock owners receive no direct consumption benefits, and their investment benefits are associated with expected rental returns to their reinvestments. On the other hand, tenants solely receive consumption benefits from their reinvestments; yet this benefit is a function of their length of stay. Therefore, owner-occupiers are likely to display higher reinvestment levels than other Hhs.

Rental stock owners, on the other hand, are likely to undertake reinvestment work either to secure their initial investments or to capitalize higher rental income where possible. This may in turn be controlled by other factors like location and age of buildings. Tenants, having high mobility rates and considering the possibility of eviction, are expected to undertake only essential reinvestments for their own consumption, displaying low levels of expenditures. A sub category for tenant Hhs can be identified as 'privileged tenants' (Balamir, 1992). Privileged tenants are Hhs living with parents or in relatives' dwellings, paying rents below market levels or no rent at all. This group of Hhs may be in the expectation of moving out either to their own, or inheriting the unit in the long run. Two possibilities for reinvesting may arise in the case of 'privileged tenants'. If the Hhs are expecting to inherit the dwelling unit then their reinvestment behaviour could be similar to owner-occupiers. If the expectation is moving out (e.g. newly married couples) then Hhs could refrain from reinvesting in the existing dwelling. These differing incentives to undertake reinvestment burden also have implications on timing of reinvestments. Owner-occupiers, for instance, are expected to respond reinvestment needs as soon as possible if no budget constraints, technical problems, and mobility plans in near future prevail. However, rental stock owners are likely to realize reinvestments especially when they have high expectations of capitalizing higher returns like external causes. For tenants, the times immediately after their move to the dwelling may be the most preferable time for reinvestments in order to obtain maximum consumption benefits. Lack of data prevents to investigate reinvestment decisions of the rental stock owners empirically. However, reinvestments in urban areas, in terms of repairs and maintenance expenditures per owner-occupier Hhs, tenants, and privileged tenants can be observed in Figure 2 (8).

Accordingly, expenditures on owner-occupied stock display higher levels compared to rental stock in every year observed. No information however is available on reinvestment expenditures of the rental stock owners, regarding units they rent to tenant Hhs. On the other hand, expenditures of privileged tenants display always higher levels than tenant Hhs, and

8. It is not possible to differentiate repairer and non-repairer Hhs in the Household Consumption Expenditure Database. Therefore, average 'expenditure per $\mathrm{Hh}^{\prime}$ is calculated for each tenure mode by dividing total repairs maintenance expenditures to all Hhs in that tenure category. lower levels than owner-occupants. This result is in line with these Hhs position since they are neither owner-occupiers nor tenants. In the light of this information it can be stated that, high rates of depreciation are likely to appear in areas where tenants dominate the housing stock, thus loss of quality is to emerge faster and will be more significant in such urban 
Figure 2. Monthly Average Repairs and Maintenance Expenditures per Urban Households with respect to Mode of Tenure (2008 constant prices). TURKSTAT, Household Consumption Expenditure Database (2002-08).

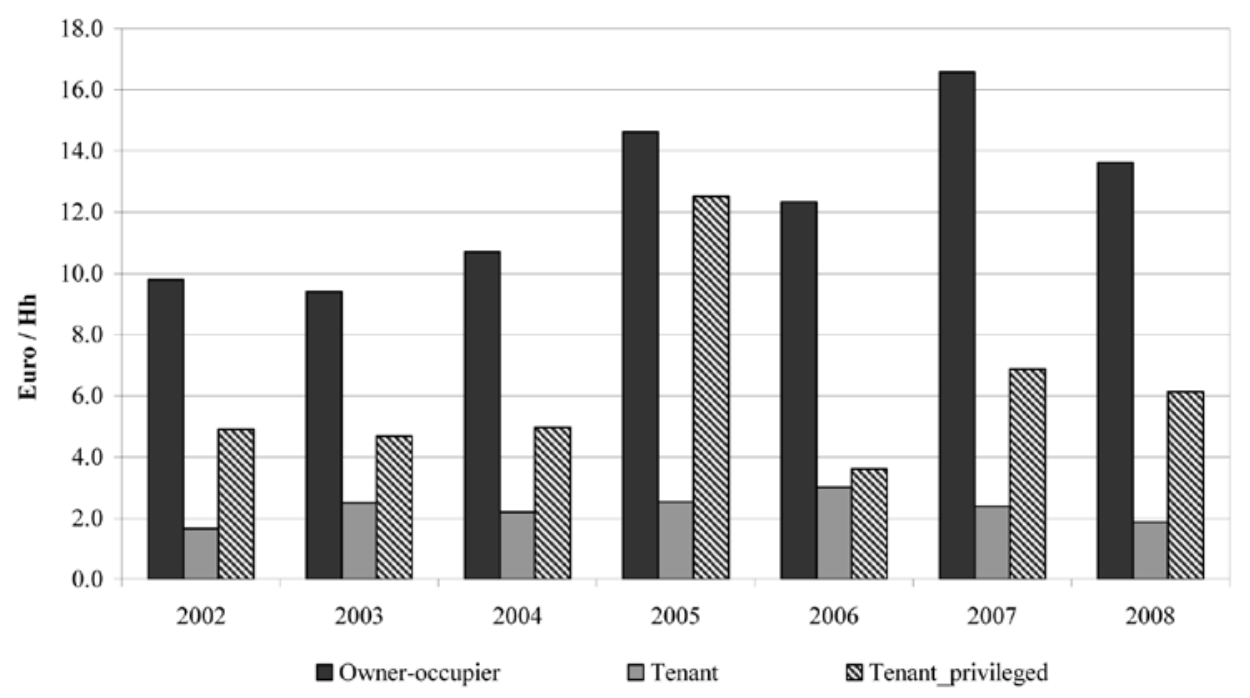

environments. Development of local policies for the preservation of quality and standards in such urban areas should attract greater attention.

Turkish Hhs' reinvestment expenditures also have implications in the construction sector and thereby in the overall economy. Of the total volume of Hhs' reinvestment expenditures realized in 2008, 49 per cent were payments for professional services, whereas 51 per cent were for material purchases. In other words, Hhs' reinvestments in the existing stock create demand for services and materials in the construction sector. In 2006, reinvestment works were estimated to represent 14 per cent of the internal market of construction materials industry, and 6500 registered firms, material and service providers, are known to exist in the sector by the same year (YEM, 2007). In times of recessions in the economy, as new investments are reduced, promotion of reinvestment activities may be a tool to stimulate production activity in the construction sector, and maintain demand for labour.

Data limitations make it difficult to investigate other implications of Hhs' reinvestment behaviour at the macro level. For instance, statistical data regarding extensions, upgrading, joining and subdividing decisions in the existing housing stock are not available in 'Building Permit Statistics', provided by TURKSTAT. This leaves no room for investigating implications of Hhs' reinvestment decisions on the supply of housing. Due to limitations of statistical data, significant dimensions of reinvestment issues, which can provide vital inputs to housing policies, remain unavailable in the Turkish case.

\section{PRIORITY OF REINVESTMENT POLICIES IN TURKEY}

The problem of housing has been largely considered as a quantitative problem in Turkey for many decades. Even in the current 'urban transformation' efforts, reasoning cannot go beyond the conventional arguments for increasing housing production by means of physical redevelopment of urban areas. Thus, reinvestments in the existing housing stock have attracted almost no attention in Turkey. This attitude could have been considered relevant and satisfactory at the earlier stages of urbanization. However, with greater mobility and access to information, 
Figure 3. Number of Urban Dwelling Units and Urban Households: 1955-2006. Updated from Balamir (2002); TURKSTAT, Census of Population (2003a), Building Permit Statistics (2008a), Household Consumption Expenditure Database (2002-08).

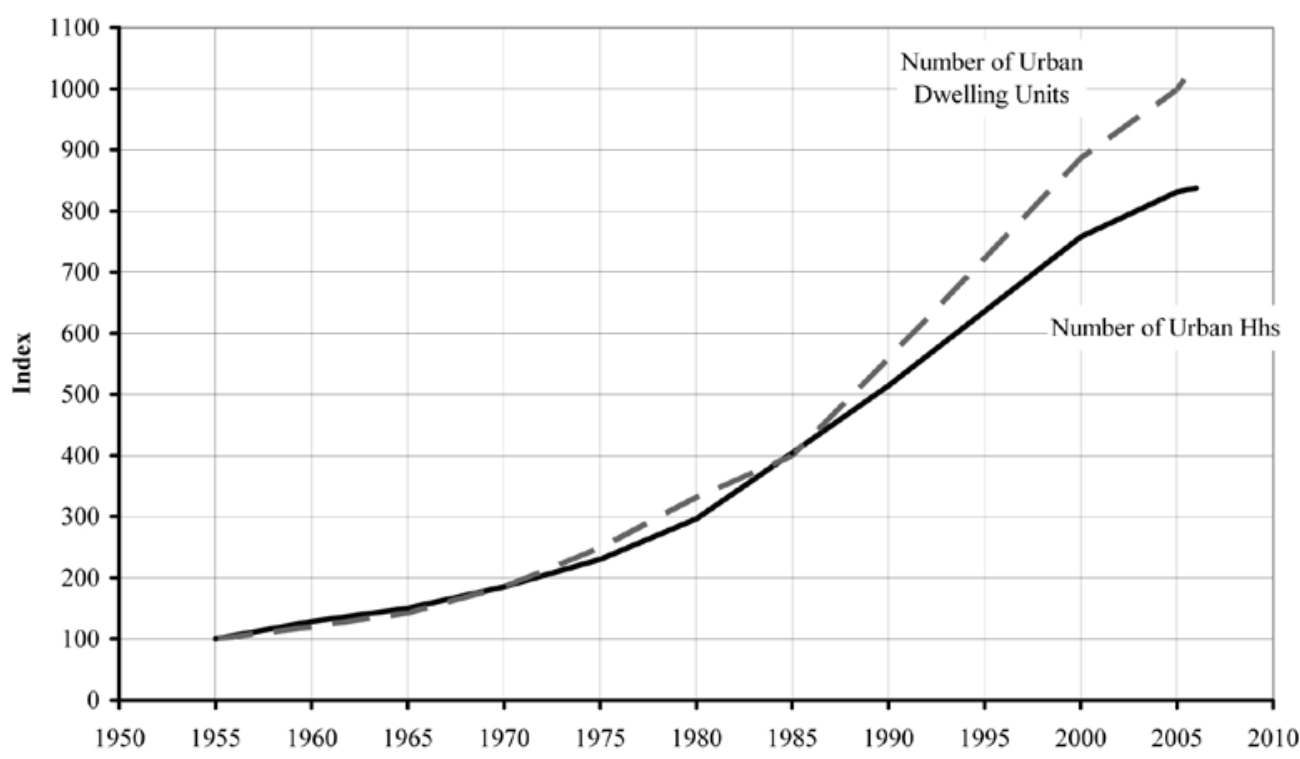

availability of credits and capital, removal of constraints on imports, expansion in construction materials, industrialized upgrading skills, kits, and packages etc. every condition prevails today for extensive reinvestment activities. There are numerous reasons to design and implement reinvestment policies in the existing housing stock and urban environments in Turkey (9).

The most striking reason that urgently calls for the provision of reinvestment policies in Turkey is the need and rising demand for the achievement of safer and higher standard urban environments (10). Another reason that calls for the provision of reinvestment policies is the new phase of urbanization in Turkey. This phase is characterized by declining annual population growth, slowing down of rural to urban migration, and formation of a significant excess housing stock in urban areas curbing the need for additional new housing production. Annual average population growth rate in Turkey has displayed a decrease from $24.9 \%$ o to $18.3 \%$ in $1980-85$ and $1990-2000$ periods respectively (TURKSTAT, 2003a). Moreover, the share of the population living in urban areas has reached to 70 per cent of the total population in year 2007 (TURKSTAT, 2008b). Therefore, it is not realistic to expect further population increases and high rates in urban growth, compared to the dramatic increases of the 1950's and 1960's. Furthermore, the total number of dwelling units exceeds the number of Hhs in urban areas (Figure 3), and approximately 25 per cent of excess in the authorised housing stock is known to exist in the aggregate by year 2006, with some geographical differences (11). Detailed information, however, on the quality and standards of the existing housing stock does not exist in Turkey. Even so, considering the above mentioned demographic and construction trends it can be argued that qualitative aspects of the housing problem need to be a current priority of housing policy in Turkey rather than quantitative considerations.

New housing production is expected to fall consequent to above mentioned trends and circumstances in urban areas. On the contrary, during 20022006 annual housing production had artificially increased at an accelerated unauthorised parts of the stock as censu data and HBS estimates cover all Hhs. 
Figure 4. Annual Housing Starts in Urban Areas According to Construction Permits: 1966-2008. TURKSTAT, Building Construction Statistics (2003b), Building Permit Statistics (2009).

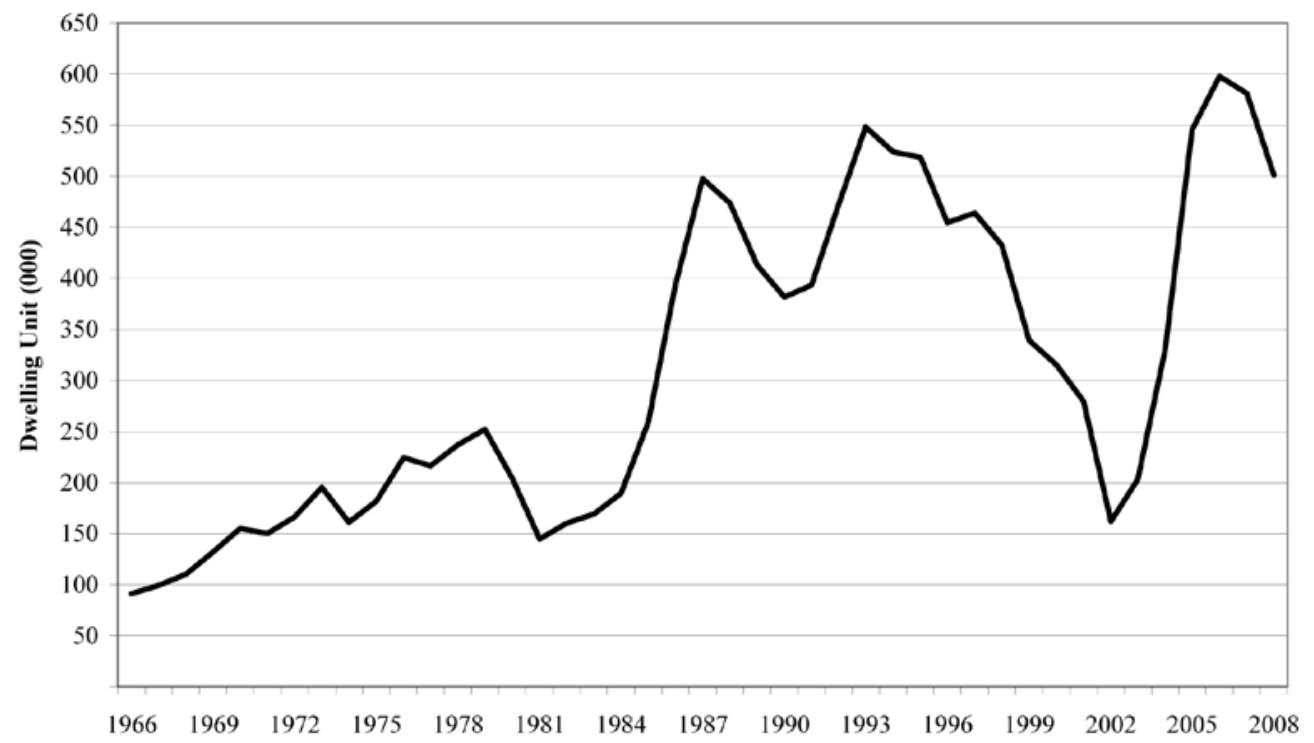

rate never observed in the last 20 years of Turkish urbanization history (Figure 4). This inflation in housing starts was a result of the deliberate policy of government in office. Annual new housing construction went an upswing, and from 162,000 units in 2002, peaked almost to 600,000 units in 2006. This figure comprises almost 3.5 per cent of the existing housing stock in 2006 (TURKSTAT, 2001, 2003b, 2008a.). It is a fact that, new construction responding to current needs, and employing new materials and new construction technologies is always needed. Yet, 'new housing production' need no longer be the priority for urban policy in Turkey. As Bademli (1992) highlights, during the periods of lowering rates of growth in urbanization, urban agenda should comprise 'urban repairs and improvements in the quality of existing urban environments' rather than 'urban growth and quantity considerations'.

The ownership regime in Turkey forms another reason for considering reinvestment policies as a requirement. Both owner-occupied and rental stock in Turkey is privately owned. Most of this stock has been produced within a short-span of time and is being aged altogether. The relevance of reinvestment policies becomes more evident considering the fact that all types of reinvestments are totally left to Hhs' decisions in the free market. Furthermore, this stock is dominated by apartment blocks where decision-making power on buildings is unconditionally fragmented and the possibility of producing joint decisions is minimized. As Balamir (1975) underlines, ownership fragmentation in buildings is to hinder realization of redevelopment decision in free market environment at future stages of urban lifecycle, "leading large sections of the Turkish cities into paralysis". Therefore, individual reinvestment efforts are expected to increase as this stock ages. In the absence of reinvestment policies it is not possible to monitor quality of life in the existing housing stock and urban environments.

Furthermore, current conditions in financial markets and construction sector favour reinvestments in the existing housing stock. This means that social and economic significance of reinvestments in the context of housing and development in Turkey is likely to dominate. Consumer loans with low interest rates, which have become available in recent years, could 
12. Volume of housing loans consisted 20 per cent of total consumer loans (283 million \$) in year 2002, and by 2005 this figure had doubled reaching 44 per cent $(9,210$ million $\$)$, and 47 per cent $(26,604$ million $\$)$ by 2007 (derived from Banking Regulation and Supervision Agency - BRSA). Moreover, monthly interest rates for housing loans declined from 2.57 per cent levels in mid 2004 to 0.99 per cent at the end of 2005 (Doğan, 2006). As of September 2010, it rules at 0.95 1.05 per cent levels. Loans for repairs and maintenance activities and retrofitting, on the other hand, are available with shorter repayment periods, 1-36 months, compared to housing loans. Detailed information on these types of loans are difficult to obtain since they are usually provided in the 'other loans' category of the available data sources. Monthly interest rates for these loans rules at 1.40-1.50 per cent levels as of September 2010. trigger reinvestments. Hhs can employ these loans in order to purchase a home, afford repairs and maintenance expenses, or to meet other Hh needs (12). Additionally, introduction of higher quality materials, components, new designs and technological developments are effective inducers in reinvestments. Various new construction materials and components have gradually become available in the market with the removal of constraints on imports during 1980s. This was followed by specializations in the subsectors of the industry in terms of new services provided for painting, prefabricated construction, kitchen-bathroom modules, roof repairing, insulation, woodwork etc. Moreover, specialized fairs for materials and components have become regularity, contributing to the sector's development with the participation of leading firms in the international markets. Interior design as a professional occupation and specialization gained momentum in response to changing material conditions. In addition to these, increasing numbers of 'do it yourself' (DIY) kits trading have become available in the construction materials market. Consequently, availability of various construction materials and an increasing number of specialized firms in reinvestment works promote and facilitate reinvestments especially when supported with consumer loans that finance such activities.

Many other reasons may prevail for considering social and economic significance of reinvestment trends in the context of housing and development in Turkey. As observed above, the major challenge for Turkey in the coming decades is not in the increasing of new housing production; rather it is maintaining and improving standards of living and quality in existing housing stock and urban environments. In this context, a thorough understanding of Hhs' reinvestment behaviour, as major actors of reinvestments, is needed in order to contribute to the structuring of complementary policies in the housing system and designing methods of intervention in the existing housing stock and neighbourhoods.

\section{CONCLUSION}

For many decades, reinvestment issues have been ignored by Turkish urban planning and housing policies. Current 'urban transformation' efforts also overlook the option of improving existing urban environments by means of reinvestments. However, the major concern for Turkey in the decades ahead is to design and implement reinvestment policies, as complementary policies in the housing system, in order to maintain and improve standards of living and quality in existing housing stock and environments. Considering the fact that almost all of the housing stock in Turkey is privately owned, and all types of reinvestments are totally dependent on Hhs' decisions in the free market, the crucial role of Hhs' reinvestment decisions in the prospects of nation's housing stock and neighbourhoods can be understood. Therefore, the major challenge in designing reinvestment policies could be considered to depend on an understanding of the dynamics of Hhs' reinvestment decisions. This is also true for the understanding of aggregate consequences of individual reinvestment behaviour in built environment and in the overall economy. Therefore, a thorough investigation of causes and macro implications of Hhs' reinvestment decisions is imperative for further studies.

Hhs' reinvestment behaviour have implications on depreciation of the housing stock, quality of housing and neighbourhoods, housing adjustment options, housing supply, and overall residential expenditures and 
consumption. Understanding the macro implications of Hhs' reinvestment behaviour can provide inputs in the designation of macro objectives in housing policies and urban planning. Comprehensive information about internal dynamics of Hhs' reinvestment behaviour based on indicators concerning characteristics of Hhs, dwellings, and neighbourhoods, and external factors are necessary. Systematic information on adjustment strategy options adopted by Hhs (stay-reinvest, stay-do nothing, move, move and improve, etc.), scale and types of reinvestment work, volume of reinvestment expenditures, and the motivation underlying these investments (consumption or investment purposes) are essential for structuring complementary policies in the housing system. Reinvestments in distinct housing environments may require different types of tools and mechanisms. Perception of the problem as a local one with its own constraints and potentials is necessary to develop flexible frameworks and adaptable mechanisms. Such an approach could have immediate impact in the improvement of the quality of life in cities.

\section{ACKNOWLEDGEMENTS}

This paper is partly based on the author's Ph.D. dissertation at Technical University of Dortmund. The author would like to thank Prof. Dr. Murat Balamir for his invaluable guidance throughout the study.

\section{ABBREVIATIONS}

BRSA: Banking Regulation and Supervision Agency

DIY: Do It Yourself

HBS: Household Budget Survey

Hh: Household

SPO: State Planning Organisation

TURKSTAT - TÜIK: State Institute of Statistics

YEM: Building Information Centre (Yapı-Endüstri Merkezi)

\section{REFERENCES}

ARNOTT, R., DAVIDSON, R., PINES, D. (1983) Housing Quality, Maintenance and Rehabilitation, Review of Economic Studies (50) 46794.

BADEMLİ, R. (1992) New Agenda in Urban Planning: Stagnated Urbanization (pub. in Turkish), Kent Kooperatifçiliği Yedinci Teknik Kongresi (1992), Türkiye Kent Kooperatifleri Merkez Birliği, Antalya; 29-37.

BALAMİR M. (1975) Flat Ownership and Urbanization in Turkey (pub. in Turkish), METU Journal of the Faculty of Architecture (1:2) 295-318.

BALAMİ, M. (1992) Flat Ownership and Urbanization in Turkey (pub. in Turkish), unpublished Ph.D. Dissertation, Ankara University, Ankara.

BALAMİ, M. (2002) Urban Rehabilitation as a Focal Subject of Current Agenda for Urban Policy in Turkey and Necessary Provisions (pub. in Turkish), Yapı Dergisi (253) 66-70.

BALL, M. (2005) RICS European Housing Review 2005, www.rics.org, accessed in July 2008.

BAUM, S. and HASSAN, R. (1999) Homeowners, Home Renovation and Residential Mobility, Journal of Sociology (35) 23-41. 
BOEHM, T. P. and IHLANFELDT, K. R. (1986) The Improvement Expenditures of Urban Homeowners: An Empirical Analysis, AREUEA Journal (14) 48-60.

BOGDON, A. S. (1992) The Determinants of Homeowner Expenditures for Renovation, Alteration and Repair, unpublished Ph.D. Dissertation, Harvard University.

BRSA, Banking Regulation and Supervision Agency, www.bddk.org.tr accessed in July 2008.

CHINLOY, P. (1980) The Effect of Maintenance Expenditures on the Measurement of Depreciation in Housing, Journal of Urban Economics (8) 86-107.

DILDINE, L. L. and MASSEY, F. A. (1974) A Dynamic Model of Private Incentives to Housing Maintenance, Southern Economics Journal (40) 631-9.

DIPASQUALE, D. (1999) Why Don't We Know More About Housing Supply, Journal of Real Estate Finance and Economics (18) 9-23.

DOĞAN, E. (2006) Developments in the Housing Loans of the Turkish Banking Sector (pub. in Turkish), Banking Regulation and Supervision Agency, Report No: 2006/1, www.bddk.org.tr, accessed in July 2008.

DONNER, C. (2000) Housing Policies in the European Union Theory and Practice, Christian Donner: Vienna.

FLAT OWNERSHIP LAW (1965) Law No: 634, Published in Official Gazette: 2/ 7 / 1965 Number-12038.

GALSTER, G. (1987) Homeowners and Neighborhood Reinvestment, Duke University Press, Durham and London.

GRIGSBY, W. G. (1963) Housing Markets and Public Policy, University of Pennsylvania Press, Philadelphia.

HANSEN, E.K., SKIFTER ANDERSEN, H. (1999) Strategies for Public Regulation of Urban Renewal and Housing Rehabilitation in Denmark, Housing Renewal in Europe, eds. H. Skifter Andersen, P. Leather, The Policy Press, Bristol; 95-113.

HARDING, J.P., ROSENTHAL, S.S. and SIRMANS, C.F. (2007) Depreciation of Housing Capital, Maintenance, and House Price Inflation: Estimates from a Repeat Sales Model, Journal of Urban Economics (61) 193-217.

HOLMANS, A. (2004) Investment in the Existing Privately Owned Housing Stock in Britain, Paper presented at the ENHR 2004 Conference, Cambridge, UK.

KNIGHT, J.R. and SIRMANS, C.F. (1996) Depreciation, Maintenance, and Housing Prices, Journal of Housing Economics (5) 369-89.

LEATHER, P. (1999) Housing Conditions and Housing Renewal Policy in the UK, Housing Renewal in Europe, eds. H. Skifter Andersen, P. Leather, The Policy Press, Bristol; 65-93.

LEATHER, P. (2000) Crumbling Castles? Helping Owners to Repair and Maintenance Their Homes, Joseph Rowntree Foundation, www.jrf.org. uk, accessed in September 2008. 
LICHFIELD, N. (1956) Economics of Planned Development, Estates Gazette, London.

LITTLEWOOD, A. and MUNRO, M. (1996) Explaining Disrepair: Examining Owner Occupiers' Repair and Maintenance Behaviour, Housing Studies (11) 503-25.

LITTLEWOOD, A. and MUNRO, M. (1997) Moving and Improving: Strategies for Attaining Housing Equilibrium, Urban Studies (34) 1771-87.

MANDIČ, S. (2001) Residential Mobility versus 'In-place' Adjustments in Slovenia: Viewpoint from a Society 'in Transition', Housing Studies (16) 53-73.

MAYER, N. S. (1981) Rehabilitation Decisions in Rental Housing: An Empirical Analysis, Journal of Urban Economics (10) 76-94.

MENDELSOHN, R. (1977) Empirical Evidence on Home Improvements, Journal of Urban Economics (4) 459-68.

MERRETT, S. (1982) Owner Occupation in Britain, Routledge and Kegan Paul, London.

MONTGOMERY, C. (1992) Explaining Home Improvement in the Context of Household Investment in Residential Housing, Journal of Urban Economics (32) 326-50.

OXLEY, M., GOLLAND, A., HODGKINSON, S. and MAYE-BANBURY, A. (1999) Findings: European Approaches to Financing Owner-Occupied Housing Repair and Maintenance, www.jrf.org.uk, accessed in September 2008.

ÖZDEMIR SARI, Ö. B. (2007) Mevcut Konut Stokunda Yeniden Yatırım: Hanehalkı Davranışının Üst Ölçekte Etkileri, Planlama (2007) 35-42.

POTEPAN, M. J. (1989) Interest Rates, Income, and Home Improvement Decisions, Journal of Urban Economics (25) 282-294.

RESCHOVSKY, J. D. (1992) An Empirical Investigation into Homeowner Demand for Home Upkeep and Improvement, Journal of Real Estate Finance and Economics (5) 55-71.

SEEK, N. H. (1983) Adjusting Housing Consumption: Improve or Move, Urban Studies (20) 455-69.

SHEAR, W. B. (1983) Urban Housing Rehabilitation and Move Decisions, Southern Economics Journal (49) 1030-52.

SHILLING, J.D., SIRMANS, C.F. and DOMBROW, J.F. (1991) Measuring Depreciation in Single-Family Rental and Owner-Occupied Housing, Journal of Housing Economics (1) 368-83.

SINAI, I. (2001) Moving or Improving: Housing Adjustment Choice in Kumasi, Ghana, Housing Studies (16) 97-114.

SKIFTER ANDERSEN, H. (1999) Housing rehabilitation and urban renewal in Europe: a cross-national analysis of problems and policies, Housing Renewal in Europe, eds. H. Skifter Andersen, P. Leather, The Policy Press, Bristol, 241-77.

SKIFTER ANDERSEN, H. (2008) Is the Private Rented Sector an Efficient Producer of Housing Service? Private Landlords in Denmark and their Economic Strategies, European Journal of Housing Policy (8) 26386. 
SPO (2007) Settlement and Urbanization Ad-hoc Committee Report, 9th Development Plan 2007-2013, Publication No DPT: 2708-ÖİK: 661, Ankara.

SWEENEY, J.L. (1974) Housing Unit Maintenance and the Mode of Tenure, Journal of Economic Theory (8) 111-38.

TURKSTAT (2001) Building Census 2000, Publication No: 2471, Ankara.

TURKSTAT (2002-08) Household Consumption Expenditure Database, www. tuik.gov.tr, accessed in December 2010.

TURKSTAT (2003a) 2000 Census of Population: Social and Economic Characteristics of Population, Publication No: 2759, Ankara.

TURKSTAT (2003b) Building Construction Statistics, Publication No: 2938, Ankara.

TURKSTAT (2008a) Building Permit Statistics 2006, Publication No: 3117, Ankara.

TURKSTAT (2008b) News Bulletin, No: 154, 18.09.2008, www.tuik.gov.tr, accessed in November 2008.

TURKSTAT (2009) Building Permit Statistics 2008, Ankara.

U.S. Census Bureau (2001) Current Construction Reports, www.census.gov, accessed in July 2008.

WILHELMSSON, M. (2008) House Price Depreciation Rates and Level of Maintenance, Journal of Housing Economics (17) 88-101.

WINGER, A. (1973) Some Internal Determinants of Upkeep Spending by Urban Home-Owners, Land Economics (49) 474-9.

YEM, The Building Information Centre (2007) Turkish Construction Sector Report (pub. in Turkish), YEM, İstanbul, Turkey.

Alındı: 05.04.2011, Son Metin: 05.10.2011

Anahtar Sözcükler: konuta yeniden yatırım; iyileştirme; hanehalkı davranışı; konut politikası; Türkiye konut sektörü.

\section{MEVCUT KONUT STOKUNDA HANEHALKI YENIDEN YATIRIM DAVRANIŞI VE ÜST ÖLÇEK ETKİLERİ}

Mevcut konut stokunda yeniden yatırım, konut stokunun sunduğu hizmetlerin ve yaşam standardının iyileştirilmesini amaçlayan bakımonarım faaliyetlerini ve rehabilitasyon yatırımlarını ifade etmektedir. Çoğu ekonomilerde olduğu gibi, konut stokunda yeniden yatırım kararı ülkemizde de hanehalkları tarafından verilmektedir. Hanehalkı yeniden yatırım davranışı her ne kadar mikro düzeyde bir eylem olarak görünse de hanehalklarının bireysel faydalarından çok daha kapsamlı etkileri olduğu iddia edilebilir. Bu etkilerin bir kısmı yapılı çevrede gözlenebilirken, diğerlerini ekonominin genelinde takip etmek mümkündür. Ülkemizde konut stokunun neredeyse tamamı özel mülkiyet altındadır ve her türlü yeniden yatırım kararında hanehalkları temel aktördür. Bu nedenle hanehalklarının yeniden yatırım kararlarının mevcut konut stokunun yıpranmasının ve yaşam çevrelerinin kalitesinin temel belirleyicilerinden biri olduğu söylenebilir. Hanehalklarının yeniden yatırım harcamalarının 2007 yılında 1,83 milyar Euro düzeyine ulaştığı, küresel ekonomik krizin etkilerinin görüldüğü 2008 yılı itibariyle ise 1,42 milyar Euro 
düzeyinde olduğu tahmin edilmektedir (TÜİK, 2002-08). Diğer bir deyişle, hanehalklarının yeniden yatırım amacıyla konutlarına yaptıkları harcamalar ülke genelindeki toplam konut yatırımlarının kayda değer bir parçasıdır. Ayrıca, hanehalklarının konuta yeniden yatırımlarının inşaat sektörü için, dolayısıyla ekonominin bütünü için de etkileri olduğunu söylemek olanaklıdır. Hanehalkı yeniden yatırım harcamaları inşaat sektöründe hem hizmet, hem de malzeme için talep yaratmaktadır. 2006 yılı tahminlerine göre yeniden yatırım işlerinin inşaat malzemeleri sanayisinin iç pazarındaki payı \% 14'tür (YEM, 2007). Ayrıca, 2006 yılı itibariyle sektörde bu alanda hizmet ve malzeme sağlayan 6500 kayıtlı firma olduğu bilinmektedir.

Mevcut konut stokunda yeniden yatırım Türkiye' de güncel bir kentsel ekonomik eğilim olduğu halde bu konu araştırmacılar ve karar vericiler tarafından neredeyse tamamen ihmal edilmiştir. Oysa yeniden yatırım konusunda ivedilikle politika tasarlamak ve uygulamak için birden çok neden sayılabilir. Bu nedenlerden ilki kentlerimizde deprem ve sel felaketlerine karşı dirençli ve güvenli kentsel çevreler yaratmak ihtiyacıdır. Ayrıca, ülkemiz kentleşmesinin bugünkü aşamasında yıllık nüfus artış hızının azalma eğiliminde olduğu, kente olan göçün yavaşladığı ve ülke genelinde kentsel konut stoku üretiminin kentsel hanehalkı sayısının oldukça üzerinde seyrettiği bilinmektedir. Böyle bir ortamda, konut politikalarının önceliğinin yeni konut üretimini teşvik etmekten ziyade mevcut kentsel çevrelerin ve konut stokunun niteliğinin iyileştirilmesi olması beklenir. Türkiye'de yeniden yatırım politikaları tasarlanması ve uygulanması ihtiyacının bir nedeni de mevcut mülkiyet rejimidir. Neredeyse tamamı özel mülkiyet altında olan stokun büyük bir kısmı kısa süreler içinde üretilmiş ve toplu halde eskiyecektir. Çoğunluğunu apartman yapılarının oluşturduğu bu stokta karar verme erki koşulsuz olarak parçalanmış ve ortak karar verme olasılığı azalmıştır. Bu stokun serbest piyasa ortamında yenilenmesi neredeyse imkansız hale gelmiştir (Balamir, 1975). Bu nedenle bu stok yaşlandıkça bireysel yeniden yatırım girişimlerinin artması beklenebilir. Yeniden yatırım politikalarının geliştirilmemesi durumunda ise mevcut konut stokunda ve kentsel çevrelerde yaşam kalitesinin denetlenmesi mümkün olamayacaktır. Ayrıca, düşük kredi olanaklarının varlığı gibi güncel koşullar ve inşaat sektöründe hizmet ve malzeme açısından son yıllarda yaşanan gelişmeler de mevcut stokta yeniden yatırımı teşvik edicidir. Bunun anlamı, yakın gelecekte Türkiye' de konut ve kentsel gelişme bağlamında yeniden yatırımın sosyal ve ekonomik anlamının daha da derinleşeceğidir.

Hanehalkı yeniden yatırım davranışını anlamak ve bu davranışın üst ölçekteki etkilerini ortaya koymak kentsel karar vericilere ve plancilara mevcut konut stokunda ve yaşam çevrelerinde ortaya çıan problemleri çözmek amacıyla müdahale araçları ve politikalar tasarlamada girdi oluşturacaktır.

Ö. Burcu ÖZDEMİR SARI; B.CP., M.CP., Ph.D.

Studied City and Regional Planning at METU, received Ph.D. in Political Science (2010) from TU Dortmund, Faculty of Spatial Planning. Worked at METU as a research assistant (20012007). Currently teaching 'Urban Economics' at METU, Department of City and Regional Planning as part-time instructor. Areas of interest are housing studies, urban economics, and household behaviour. bozdemir@arch.metu.edu.tr; $\underline{\text { bozdemir.sari@gmail.com }}$ 
